\title{
"Only your picture in my mind": the image, the heart, and the mirror in some seventeenth-century poems
}

\author{
DOSIA REICHARDT \\ James Cook University, Cairns
}

\begin{abstract}
La subjectivité aux débuts des temps modernes demeure un thème d'un grand intérêt. Toutefois, les « poèmes au miroir » de Cavalier, caractérisés par l'inversion étrange qu'il fait subir à la logique usuelle de la louange propre au lyrisme amoureux, ont été particulièrement négligés. Cet article examine donc la façon de réagir qu'ont les poètes face au spectacle d'une femme absorbée par son miroir. Les récits d'Ovide au sujet de Echo et Narcisse servent d'assise à cet examen des anxiétés de nature sexuelle et à leur évocation du masochisme ironique de Marvell. Les amoureux masculins du milieu du $\mathrm{XVII}^{e}$ siècle tendent dans les « poèmes au miroir » à perdre leur identité en échange de qualités féminines apparentées à l'affliction. De superbes et froides maîtresses deviennent simultanément des Narcisses (présentées comme vaniteuses et ridicules par Ovide) ainsi que leur dur reflet sur la surface du miroir. À une époque où la cour devait renvoyer l' image du monarque, l'exploration que ces poèmes offrent de la stérilité de ce procédé comporte à la fois des sous-entendus politiques, et une retraite non seulement en campagne - comme Cavalier l'a fait, mais également dans les plaisirs du texte.
\end{abstract}

$\mathrm{W}$ Then Marvell crisply invites Clora to "Come view my soul" in "The Gallery" and assures her that all she will find there is images of herself, he is commenting on a long tradition of looking-glass poems in which a woman's image is engraved on the lover's heart. Such poems employ a rhetoric of persuasion to lure the woman away from her mirror. In the mid seventeenth-century, these poems, with their debts to Continental writers, are found predominantly (and consistently) in the works of Royalist poets. In poems by Carew, Stanley, Kynaston, and others the architecture of the poet's mind and the creation of that inner space so fundamental to Western subjectivity are explored. Some of these poets reveal their affinity with the post-modern decentred subject. Rather than being on the cusp of early modern individuality, they struggle with a fragmented sense of self, insufficiently defined in relation to others and threatened with either dissolution or endless and meaningless replication. Cavalier looking-glass poems express a psychological insight derived from medieval theology: "Our need for others depends not so much on our need for

Renaissance and Reformation / Renaissance et Réforme 30.2, Spring/printemps 2006 
them in themselves as for our need of their image of us." ${ }^{\text {"1 }}$ The lovers seek to probe into each other's souls only to find flattering reflections of themselves, and the woman seems less interested in the man than in her own beauty. A poem or a doting lover are better than a mirror at assuring her that her beauty is lasting. But the insight gained from such poems is partial; there are no looking-glass poems or even answers to them written by women in this period to provide perspective. Marjorie Swan has argued that the unsatisfactory nature of Cavalier self-regard lies in its implicit rejection by the woman of a definition through male eyes, but this rejection is only evident through the supplicating tones and abject stance of the male poet. ${ }^{2}$

The Cavalier poems discussed here are the heirs of the Renaissance and of mirror sonnets deriving from Ovid and from Petrarch's Rime, but they depart from Donne and Jonson and also from poems by Shakespeare and Spenser that treat the mirror as a rival, but where the poet still retains his own identity. ${ }^{3}$ In A moretti 7, for instance, Spenser manipulates a complex set of reflections: the eye is the mirror of one's own heart while the lover is himself reflected in the eyes of the beloved. In this endless reflexivity, however, the lovers are united. The type of comparison which equates the lover with Narcissus, and the unattainable female with the reflection (as in Ronsard and Spenser), is reversed. In The Faerie Queene Spenser introduces a magic mirror which, while providing visions of distant things, can also blind the wisest. There is no foreshadowing of the credulity ascribed to pastoral ladies by poets at the Stuart court, and the complexity of mirror images found in Renaissance writers is reduced. Looking-glass poems did not survive the Restoration; they disappeared altogether except as dramatic props in comedy or in eighteenth-century satires on women at their dressing tables by Swift and Pope. These return, in a more virulent form, to those Renaissance conduct manuals in verse: the admonitory poems that seek to turn a woman away from vanity and from mirrors, and which found favour in the mid-century among those lovers of wine, women, and song whose attitudes might be expected to be more congenial.

I shall focus first on those lyrics, sententious in tone, that appear to encourage spiritual reform through the use of a mirror while reinforcing the image of a woman with a mirror as an archetypal representation of feminine weakness. These poems identify vanity, idolatry, and egoism as feminine traits and are in the tradition of such moral tracts and pamphlets as A Mirrhor of Modestie, which themselves mirror medieval exemplars. ${ }^{4}$ In admonitory verses, the mirror metaphor is the one familiar from many conduct books; the speaker of the verse is absent, content to describe an interchange between a woman and a mirror. Such poems argue that by seeing images of oneself, the discrepancy between image and essence is revealed, 
leading to agendas of reform (Prudentia) or despair (Narcissus). 5 The focus is on the danger of specifically female Narcissism. In both art and poetry of the period, a male figure before a mirror is rare. ${ }^{6}$ Marvell explicitly praises Lord Francis Villiers for his martial rejection of a looking glass:

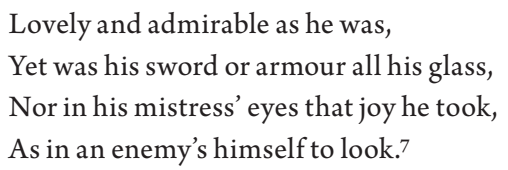

Love lyrics of the early and mid-seventeenth century commonly draw attention to the aesthetic charms of the female body. The iconic description of the beauties of a supposedly specific mistress is often the first step in a parabolic argument for the woman surrendering herself. The period is rich in examples, such as Edmund Waller's popular song "Go Lovely Rose" in which he urges, "Small is the worth / Of beauty from the light retir'd; / Bid her come forth, / Suffer her self to be desire'd." ${ }^{8}$ This stance is regarded as typically Cavalier and shades into poems which are more frankly erotic and libertine and can easily be seen to objectify, dismember, and seduce the silent other. But looking-glass poems invert the logic of praise and reveal a sterner, more complex set of attitudes towards gender relations. The woman attached to her mirror is overvaluing an image, while the poet (like the logocentric Puritans) reshapes it in words. While expressing homage to beauty, mirror poems deny its importance in favour of inner virtue, and privilege the soul over the body. ${ }^{9}$ James Shirley's "To a L. upon a Looking-Glasse Sent" urges the woman to use her mirror as a means of comparing her "outward grace" with her "inward beauty." 10 The topic was popular in the manuscript miscellanies of the time, as an anonymous poem, identical in theme with Shirley's, indicates:

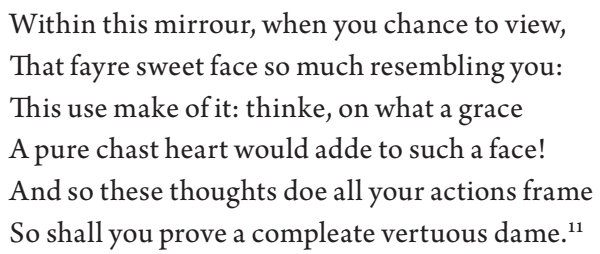

The importance of spiritual purity is also taken up by Robert Heath in "To a Lady wearing a Looking-glass at her girdle." ${ }^{12}$ First he urges that the mirror be discarded because it shows only the "dust" of the external body. Then he suggests (unusually in this sub-genre of poems) that the mirror does not provide a true representation, and compares it with the effusive praise of "fond admirers" and "spruce gallants" which the female would be foolish to believe. Having undermined the poetic 
enterprise on which his own poems to Clarastella also rely, he asks "When knowing men dissemble truth: alas! / Will you then trust a dumb deceitful glass?” Despite the mirror's unreliability the woman is still subject to falling in love with herself, as did Narcissus, but while she is distracted the poet's agenda is revealed. The admirer really wishes to view neither her face, nor the soul that "wise men admire," but those dark and usually hidden parts. Just as the white plumes of the swan conceal "her own black skin," the mermaid with her glass and comb hides what "we all know / You'ar either fish or what is worse, below." The paternalistic, Puritan tone disguises the fear and dislike of women's sexuality and agency evident in other poems that urge the woman to leave her mirror. Spiritual health is a surface concern and is in the tradition of women's conduct books, but two other consequences of excessive vanity dislodge the usual confidence of poets: the woman will use the mirror to apply cosmetics (usurping the mirror's function of providing a "true" reflection) or she will be so enamoured of her own image that the lover will effectively disappear from view. The latter point of view is aptly summarized by Abraham Cowley when he asks: "Can that for true love pass. / When a fair woman courts her glass?"13

During the seventeenth century, mirrors became more common as household objects, and the poetic censure provoked by their use indicates not only their ubiquity, but also the anxiety provoked by women who could use them to alter their appearance. ${ }^{14}$ In Renaissance paintings the sirens were portrayed with mirrors, and Venus (linking vanity with lust) was often shown with a mirror. A woman busy with her mirror, not content to be simply the reflection of man as man was of God, was likely to be not simply viewing, but also creating an image for herself and for the world. Women with mirrors are by implication unchaste, vain, and themselves hard as any reflective surface, as one anonymous writer finds: "Ah cruel Glasse didst thou not see, / Chloris alone too hard for me?"15 This reversal of conventional classically-derived gender attributes is also evident in other mirror poems such as Samuel Daniel's Sonnet XxIX in which the speaker berates Delia for spending too much time gazing at her beauty in the mirror: "Then leave your glasse, and gaze yourselfe on mee," he implores. ${ }^{16} \mathrm{He}$ invokes the fate of Narcissus and predicts a worse one for Delia. Narcissus became a flower but she has turned into flint. The logical consequences of such indifference are explored by Cowley in his poem "Eccho." ${ }^{17}$ According to theories of the time, opposed qualities do not cancel each other out, but are renewed. "Shapes by reflexion shapes beget" writes Cowley, and "things by opposition grow," but "my barren Love alone / does from her stony breast rebound." The woman has become a reflective surface undisturbed by the self-knowledge Narcissus unwittingly gained when he dropped tears into his pool and became aware of his image as himself. 
Writing in the 1640s, Thomas Philipottt warns an anonymous woman that frequent recourse to her glass to check her face or dress will only remind her of the mortality and frailty of the tenement she lavishes with costly cosmetics. ${ }^{18}$ Eldred Revett spends over 50 lines complaining about the fashion for painted black beauty spots on "natures own clean manuscript." 19 The practice has been aided by use of a glass through which the woman addressed also falls into "your own idolatry." The latter danger is uppermost in Thomas Randolph's "To one admiring Herself in a Looking-glass," which describes a woman who is so lovely that she may be beguiled by her own beauty into rejecting the world entirely. ${ }^{20}$ Randolph's poem opens with a flattering description of the unnamed woman, but he also finds her vain: "You think no beauty is so rare / that with your shadow might compare." She is in danger of falling into the trap that awaited Narcissus:

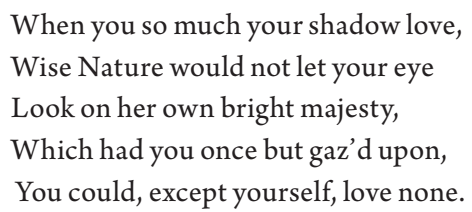

Once the mirror has also been rejected, however, the previously discarded lover can draw the woman's attention back to himself in an equal exchange of "dues." Randolph's poem introduces the element of rivalry that represents a move away from the didactic element of many Elizabethan mirror poems and sonnets towards a different register of feeling and one in which the lyric voice often finds pleasure in exploring loss. In this second group of poems the dangers of Narcissism are averted by a curious psychological twist in which the lover himself takes the place of the looking glass. The lyric voice aims at possession rather than contemplation of the image, even if that possession negates the physical.

A little known poem by Sir Francis Kynaston illustrates this unconventional use of the Narcissus myth. The story of Echo and Narcissus, derived from Ovid, resonates through much English sixteenth- and seventeenth-century drama and poetry. ${ }^{21}$ George Sandys' 1621 translation and explication of the Metamorphoses popularized it further. Ben Jonson had treated the theme in his first mythographic drama, Cynthia's Revels (1601). The motifs of illusion, beauty, and frustrated desire found in the myth proved endlessly malleable. In Kynaston's version, however, the beloved colonizes the internal spiritual space of the lover. The lover experiences an ontological self-extinction so that the woman may not be destroyed by her own beauty. Only the poet's voice, like that of the wood-nymph Echo, is left to sing the praises of the transposed image. The abject lover in Kynaston's poem to Cynthia 
has taken on the role of the unfortunate nymph who is pursued by Pan, punished by Juno, and rejected by Narcissus. His fate is that of the disconsolate Echo in Cynthia's Revels, who wishes she could have "dropt away her selfe in teares" until she could provide "a truer glasse" for her lover to gaze in. ${ }^{22}$ Kynaston had been the leader of a coterie at the court of Charles I, and had founded an academy of wits, Musarum Minervæ, in 1635. His poem to Cynthia, although belonging to an earlier period, appeared together with his verse-drama Leoline and Sydanis in 1642. Here, the poet offers not only a discrete and conventional part of his anatomy-tears, or a heart-as the substitute mirror, but his entire body. This complete dissolution of the subject in this poem is a development of the mirror-as-rival trope, of which I have found only one earlier example. ${ }^{23}$

As in other mirror poems, Kynaston's speaker desires possession; he desires the immutable fair, and he seeks to turn the beloved from error to truth. Even the purest glass will be insufficient to reflect her inimitable qualities, though jealous rivalry opens the poem: "Give me no leave, fairest Cynthia, to envy / Thy looking-glass far happier than I." (11. 1-2) 24 The rival glass is permitted to enjoy Cynthia's naked breast and also those "dainties, yet unseen by any eye" (11.14). The conflict with the mirror includes the notion that the glass not only reflects, but keeps an image of the beloved. ${ }^{25} \mathrm{~A}$ poem of praise mutates seamlessly into a lover's complaint-a process aided by Kynaston's fluid syntax and long sentences.

The poem appears to be full of gallant sentiments and self-abasement, but Kynaston's lyric persona is ambiguous. There is both pleasure and danger in the encounter with Cynthia; the body is both foregrounded and denied, the woman is both pure and contaminating. The speaker is anguished and describes himself as a melancholic in an attempt to reassert the literary masculinity of his suffering, but such melancholia betrays a crisis of agency. ${ }^{26}$ According to Lacan, developing a sense of identity necessarily places a barrier between the self and the other: looking-glass poems consistently seek to eliminate these barriers. In Kynaston's poem the lover dreams of annihilation through the appropriation of another's identity:

Thy fair looks may inanimate thy glass,

And make it my competitor: 'tis all one

To give life to a glass, as make me stone (11. 40-2).

Cynthia, as goddess of the moon, represents both inconstancy and hardnessthe very qualities of the glass that her lover becomes. The latent aggression against the female object of desire, noted by critics in many Cavalier poems, turns against the self. ${ }^{27}$ This seems to be the corollary of insisting that "a true likeness can only 
be produced by love through a process that threatens the existence of both subject and beholder-creator." 28

There is an underlying recognition in mirror poems that the adulation of women in Petrarchan style is a poisonous fiction that fractures not only the woman-in the way many critics of the blazon have noted-but also the male. Cynthia's admirer is thus literally fragmented and even willing to assimilate the negativity associated with a broken mirror since classical times. ${ }^{29}$ Mirror poems by Stanley and Carew retain the possibility of regeneration, but Kynaston's speaker faces further disintegration: "This glass of thine if thou but frown, shall fly / In thousand shivers broken by thine eye" (11. 36-7). The translation of the speaker into a looking glass implies, even without Kynaston's pointed allusion, the encounter of Narcissus with his own image. Kynaston employs more lines than usual to portray the whiteness and purity of his mistress (perhaps to suggest the white flower that Narcissus becomes), and counsels:

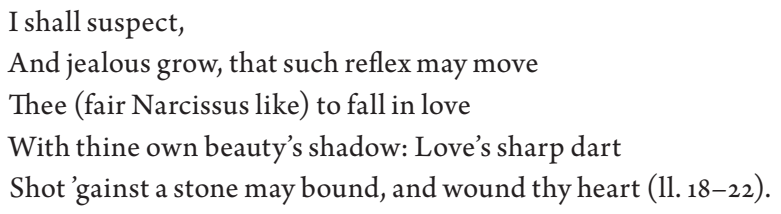

The story of Narcissus, with its potential to explore the nature of error and illusion, beauty and death, and the problems of representation, can also be used to express anxieties about identity and gender. The myth articulates the personal and social cost of self-representation in language while privileging language over love. (Ovid is more sympathetic to Echo's plight than he is to Narcissus's). While Kynaston's poem can be read as the simple desire of the poet to see his mistress naked, it also raises some problems about the nature of the poet's subjectivity. Cynthia is in danger of becoming Narcissus (attractive to both sexes), but the poet has taken on the role of the rejected female, Echo. He is prepared to become (like Echo) all voice, since his body will be either shattered or turned to stone when he himself becomes a reflection. Moreover Echo, in her Ovidian milieu, is a flatterer whose reverberating words are hollow. $3^{\circ}$

Kynaston, as a poet, is (like Echo) the child of air and language, but as an artist he is also the hapless youth who loses himself by knowing himself. The plight of Narcissus is that of the artist who deals with imagery and wishes to produce a work that reflects his meaning, but that is not just an echo or a reflection. The pool into which Narcissus gazes can give him back only himself; it is incapable of origination. In its stasis it is a parody of the creative fullness of God and his creation of the world 
ex nihilo. The tale of Narcissus in Ovid's Metamorphoses forms part of a weaving of stories in which revelation precedes destruction, and his story follows that of Zeus and the mortal Semele, who was burnt to ashes when she tried to see her lover as he really was. These myths, well known to Renaissance and early modern poets, suggest that falsification rather than replication of the image is necessary for both the lover and the poet to maintain their selfhood.

Kynaston's description of Cynthia's whiteness and purity is so hyperbolic as to raise doubts, and towards the end of his lyric Kynaston undercuts the praise and refers to the idea (derived from Aristotle) that a mirror could be tarnished if a menstruating woman looks into it. Cynthia is described as the Platonic ideal, but also as dangerous in an oblique reference to Medusa, whose mirror enables its male possessor to use the power of her image without being damaged by it. Medusa is one of the implicit and fearsome images associated with women in poetry of this period, when a "soft" mistress was preferred to a hard one. In the poem, Cynthia turns her potential lover to stone because she herself is stony. The woman's fixity represents both her immovable chastity and the gods' punishment of sexuality. ${ }^{11}$ As a sub-text of this poem the story of Medusa (who appears in Ovid, Petrarch, and Spenser) is not necessarily a narrative of male victory over dangerous and destructive women. ${ }^{32}$ In some Italian Renaissance writing, Medusa embodies artful eloquence; she is the power of language to strike an opponent dumb. ${ }^{33}$ However, by himself becoming the reflecting surface, the poet appropriates the power of reification and the image is muted into the voiceless addressee of much lyric verse. The less than perfect Cynthia may, however, have the upper hand. Kynaston is willing to turn the woman's gaze from the mirror to himself, by becoming a "body all of glass"-a transparent, delicate, and valuable Baroque object. Ovid's series of tales are about transformations which are often puzzling and painful, especially for women, but in mirror poems it is the poet who undergoes a metamorphosis that can annihilate him entirely.

Thomas Stanley also offers himself as the true and only mirror of beauty when he suggests: "Cast Chariessa, cast that glasse away, / Nor in its crystall face, thine own survey." 34 The poem opens with the usual imperative to abandon the mirror; the poet seems concerned about the spiritual wellbeing of his mistress who is likely to be charmed by her own eyes, "And thus at last fall'n with thy self in love." There is, however, less emphasis in Stanley on the Renaissance neo-Platonic associations of the myth in which Narcissus is the first victim of self-love-a soul which in aberration has turned away from its divine origin. To counter the danger of too much self-absorption, the attention-seeking poet offers himself as Chariessa's true 
representation, as the wax tablet on which she is forever engraved: "But if thou dost desire thy form to view, / Look in my heart, where love thy picture drew." This is a conventional trope but it is offered here as an alternative to the mirror, and is also a reversal of the situation imagined by Donne in "Witchcraft by a Picture" where the lover's reflection is drowned in his mistress's tears. ${ }^{35}$ His image, however, remains safely in her heart.

In his poem, Stanley employs a speaker without discernible qualities and also a discourse of passivity, but as Scott Gordon points out in The Power of the Passive Self in English Literature, many writers of the time represent the self as more formed than forming and even embrace this position. ${ }^{36}$ If the woman leaves her glass, both the poet and the beloved can co-exist in this interchangeable passivity. This neoPlatonic union is a popular motif, but is undermined by the effective disappearance of the poet-lover as an individual, except in his poem, which in turn becomes the true mirror of his identity. I have come across only two instances where the lover triumphs. In Patrick Cary's "To the tune of Bobbing Joane" the speaker whose "Brest has / In stead of Heart, a Looking-glasse" is soon cured of love, since the images of one beauty are constantly displaced by others. ${ }^{37}$

Richard Lovelace also succeeds in diverting the usually perfect Lucasta from a mirror set in ostrich feathers which she is wearing..$^{38}$ Lovelace was known for his interest in the arts and he may have been familiar with painterly depictions of female devotion to the mirror in which the lover is reduced to an accessory, holding the mirror so that his mistress can attend to hair, face, or dress. ${ }^{39}$ Lovelace's poem does not praise, but implies that the woman decked out in dyed feathers and jewels and absorbed by her own image is herself easy prey, and also that such a female will provide little inspiration for the lover or the poet. Although the woman is generally silent in looking-glass poems, Lucasta addresses her feathered mirror directly. In doing so she looks neither beyond the surface nor beyond the mirror, and demands that the looking glass remain her only companion:

\footnotetext{
My lively shade thou ever shalt retaine In thy inclosed feather-framed glasse, And but unto ourselves to all remaine Invisible, thou feature of this face!
}

The speaker in Lovelace's poem is displeased by this evidence of self-love and at being supplanted by the mirror: "Feathers and glasse to outweigh my vertue tryed?" The poem ends in violence as the putative lover, Alexis, destroys Lucasta's mirror: "Now fall'n the brittle Favourite lyes, and burst! / Amas'd Lucasta weepes, repents, and flies." The vanquished Lucasta, using the vocabulary of other mirror poems, looks 
to a different future and "vowes her self accurst / If hence she dresse herself, but in his eyes." Alexis retrieves his dominance as the mirror which will define her but without any loss of masculinity. Unlike the other writers of mirror poems discussed here, Lovelace has no desire to portray women as idealized and dominant in the precieux fashion of the court's halcyon days.

Thomas Carew is well-represented in the critical literature as a courtly lover and seducer, but in his mirror poems he also exhibits vulnerability. Addressing a supposedly pastoral mistress, he exhorts, "Fayre Doris breake thy Glasse." 40 Doris's true beauty, and essential worth, will be revealed to her only if she follows the injunction:

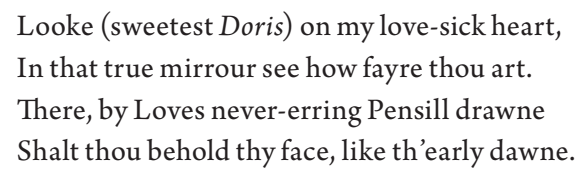

The emphasis is on the mimetic and Platonic truth of the poet's apprehension (and Carew cannot resist suggesting how superior this is to the art of the portrait painter). ${ }^{41}$ Carew is also known as a poet whose evocation of the "halcyon days" enjoyed under Charles I includes references to politics and history, and although Doris' mirror appears to be personal it still echoes other poetic mirrors that use the court and courtiers as a reflection of the sovereign, whose image, like the sun, is the originalwhich lesser mortals imitate and give back. Hamlet's many personae, for instance, are distributed via characters who act as a personal mirror. ${ }^{42}$ At the same time, the pure mind of the monarch (as in The Faerie Queene) should also be an instructive mirror for his / her subjects. As numerous explicators of mid-seventeenth century love poetry have found, there is often an analogy to political order (or disorder) in such poems, together with conservative constructions of female behaviour. ${ }^{43}$ The fragile metaphysics of such poems as Carew's replicate the equally shaky metaphysics of regarding the King as the reflection of the divine on earth. Carew's dissolving lover undermines the patriarchal appropriation of a specular source. The King, whose image fills the realm, is highly visible in the way that Doris is multiplied in her glass and in her lover's words and body. The femininity and uxoriousness of Charles's court were openly criticized by his opponents and its dangers more subtly explored in the poetry.

Like his contemporaries, Carew turns to the Narcissus myth to express his negativity about women and mirrors in two almost identical poems about a woman whose lover becomes her mirror. The supplicant's tears become the woman's accessory: 


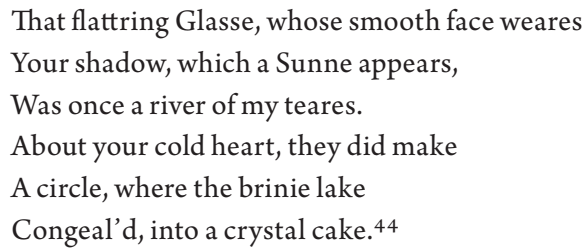

Carew, the quintessence of the courtly Stuart poet, creates here a speaker whose attributes are feminine: the poet/lover is lachrymose, overflowing, and uncontrolled. Tears were supposed to be part of a woman's armoury in love, and the emotions of fear and eros especially watery. According to Aristotle, dryness was a more desirable physical quality for males. A damp psyche was an enfeebled one; sleep, wine, and erotic indulgence all weakened masculine reason on the personal and political level. In Carew's poem it is the woman who has assimilated masculine qualities of hardness and immutability and the power to change the elements.

The sublime subjection of the lover has obliterated the lover's own image in a hyperbole which adds value to the mistress by the enormous volume of the poet's tears, so copious that they form lakes and rivers which the lady's disdain freezes into a mirror. ${ }^{45}$ These Ovidian extremes of ice and fire involve destruction but also rebirth. The lover loses his identity so that the woman may not be destroyed by her own image. D.M. Rosenberg suggests that this sacrifice is a courtly resolution: the lady now finds herself in her ardent lover rather than in a passive glass. ${ }^{46}$ However, since the lover now has no shadow, no reflection, of his own, and the woman cannot see herself without him, this neo-Platonic merging of the two represents, ironically, the fate Narcissus tried to avoid by fleeing from Echo.

Yet another crystallized lover is found in Philipott's "To a Gentlewoman viewing her selfe in her glasse." Although the poem anticipates a conventional courtly eroticism where the poet/speaker takes visual possession of the woman, its sexual frisson derives from the poet's multiple dissolutions and eventual reification into a masculine impermeability. Firstly his mistress's disdain causes him to sacrifice his life in a flood of tears; these then "Melted to a spring," and to retain its purity the spring itself "Congeal'd into a Chrystall Masse, / Of which was form'd this Looking-glasse." Philipott presents a male persona whose body is not the delineated classical one but a leaky overflowing vessel linked with the carnivalesque. ${ }^{47}$ Springs and fountains were considered feminine, and Philipott represents a patriarchal appropriation of the life-force which apparently cannot be exhausted "by profane lips" once the charitable cold has turned it to ice, then crystal. Unusually it is this specific mirror, the one formed by her lover in his entirety since his heart was insufficient to reflect 
her beauty, to which the title and the opening lines- "Cruell faire one think this Glasse, / Wherein you now behold your face"-relate. The beloved and the poet are suspended together, but the moment crystallized in the poem is no visual epiphany; there is a lack of mutuality and of regeneration.

In Carew's two mirror poems the ice can be dissolved through love and the lover and the mistress reunited, but in Philipott's the lover remains erased. By becoming her mirror, however, the poet remains a privileged viewer, even if he is only a surface. A fragile masculinity depends on being the seer not the seen, the writer not the subject, the painter not the sitter. The subject is defined via a specular relation, but through language the abject lover can retain something of the self.

Meanwhile these poet-lovers reverse the gender hierarchy derived from the Bible and expanded by Milton. In Paradise Lost Eve remains Adam's image and reflects Adam back to himself so she can be "Best Image of my self and dearer half."48 While Adam maintains the speculative, masculine gaze, Eve is presented as a type of anti-Narcissus. ${ }^{49}$ In Milton's construction of marital love both Adam and Eve reject self-love and are able to reflect instead the glory of their creator. Without positing an alternative, the looking-glass poems discussed here (and all published during the Interregnum) reveal the sterility attendant on two self-absorbed individuals and inherent in courtly love conventions. The trivialities of court life, as well as stony mistresses, have produced poets who are brittle and transparent and whose only substance is derived from the "painted shadows" of an insubstantial image.

These mid-century poems reveal the exhaustion of a tradition based on the practice of imitation, but look forward to the linguistic pleasures that characterize Marvell's poetry..$^{50}$ Through distance and despite sexual frustration the power of the female image can be absorbed by irony and detachment, for although the lover's physical presence has been erased, language is celebrated. The essential truth of the female image is still retained by the lover/poet/speaker who thus makes a plea for the validity of his own imaginative construct against the avalanche of spectacle that characterized the Stuart court.

\section{Notes}

1. John D. Lyons, "Speaking in Pictures, Speaking of Pictures: Problems of Representation in the Seventeenth Century," in Mimesis: From Mirror to Method. Augustine to Descartes, John D. Lyons and Stephen G. Nichols Jr., ed. (Hanover: University Press of New England, 1982), p. 183.

2. Marjorie Swan, "Cavalier Love: Fetishism and its Discontents," Literature and Psychology 42:3 (1996), pp. 15-35. 
3. For Shakespeare see Sonnet XxIv, "Thy beauty's form in table of my heart;" for Spenser, Sonnet VII, "Fayre eyes, the myrrour of my mazed hart" and Sonnet XLV, "Leaue lady in your glasse of christall clene" in Amoretti and Epithalamion.

4. A complete listing of mirror titles can be found in Herbert Grabes, The Mutable Glass: Mirror-Imagery in Titles and Texts of the Middle Ages and English Renaissance (Cambridge: Cambridge University Press, 1982).

5. Edward Peter Nolan, Now Through a Glass Darkly: Specular Images of Being and Knowing from Virgil to Chaucer (Ann Arbor: University of Michigan Press, 1990), p. 116.

6. One mid-century example is provided by Thomas Philipott, who addresses himself in the opening poem of his collection. See "On the beholding his face in a Glasse" in Thomas Philipott, Poems (London, 1646), pp. 1-2. G. F. Hartlaub’s magisterial survey of the mirror in Western art has only some paintings of Narcissus as exempla of a male gazing at his own reflection, in Zauber des Spiegels: Geschichte und Bedeutung der Spiegels in der Kunst (München: R. Piper, 1951). The lack of visual representation seems to underline the fear of mirrors as objects connected with female magic, with homosexual desire, and with death. The only acceptable surface for a man to see himself in would be the surface of a shield. In Tasso's Gerusalemme Liberata Rinaldo is released from Armida's enchantment only when his comrades force him to confront his feminized image in a polished shield.

7. "An Elegy upon the Death of My Lord Francis Villiers," in Andrew Marvell: The Complete Poems, Elizabeth Story Donno, ed. (London: Penguin, 1985), p. 35.

8. Edmund Waller, Poems 1645 (Menston: Scolar Press, 1971), p. 49.

9. I have found only one example of a poet allowing a woman to continue using her mirror: William Cartwright's exceptionally hyperbolic "A Panegvyric to the Most Noble Lucy Countesse of Carlisle" where he exhorts, "Hail your own Glass and Object, who alone / Deserve to see your Own Reflection," (11. 145-6) in The Life and Poems of William Cartwright, R. Cullis Goffin, ed. (Cambridge: Cambridge University Press, 1918), pp. 1-6.

10. James Shirley, Poems \& C. (London, 1646), p. 45.

11. "Upon a Looking Glasse sent to a fayre creature," Bodleian ms Rawl. Poet. 153, f. 15.

12. Robert Heath, Clarastella (London, 1650), pp. 49-51.

13. "Platonick Love," in The Collected Works of Abraham Cowley Volume 2, Thomas O. Calhoun, Laurence Heyworth, J. Robert King eds. (Newark: University of Delaware Press, 1993), p. 32. Cowley's poem, with the word "one" centrally placed, imagines genders unified through Narcissism. The looking-glass poems discussed in detail, however, depend more on an exchange of qualities usually attributed to each sex.

14. See Patricia Philippy, Painting Women: Cosmetics, Canvases and Early Modern Culture (Baltimore: Johns Hopkins University Press, 2006).

15. "Upon his Mistresse face in a Glasse" in Wit Restored (1658), Tim Raylor, ed. (New York: Scholars' Facsimiles, 1985), p. 91.

16. Arthur Colby Sprague ed., Samule Daniel. Poems and a Defence of Ryme (Chicago: University of Chicago Press, 1965), p. 25. 
17. The Collected Works of Abraham Cowley Volume 2, p. 69.

18. Philipott, "To a Lady viewing her self in her Glasse," Poems, pp. 16-17.

19. "A Lady Soild," in Eldred Revett, Poems by Eldred Revett. Poems Divine (London: 1657), pp. 36-38.

20. W. Carew Hazlitt, ed. Poetical and Dramatic Works of Thomas Randolph (London, Reeves and Turner, 1875), pp. 600-601.

21. For a comprehensive treatment see Louise Vinge, The Narcissus Theme in Western European Literature up to the Early Nineteenth Century (Lund: Gleerup, 1967).

22. Ben Jonson, Cynthia's Revels, or The Fountaine of Self-Love, I.ii. 29-39, in Ben Jonson's Plays in Two Volumes, intro. Felix. E. Schelling (London: J.M. Dent, 1960), vol. 1, p. 157.

23. "Qual da cristallo lampeggiar si vede," CLXIX, Rime D'Amore Libro II, in Opere di Torquato Tasso, Giorgio Petrocchi, ed. (Milano: Ugo Mursia, 1964), p. 571.

24. Sir Francis Kynaston, Leoline and Sydanis. A Romance of the Amorous Adventures of Princes. Together with sundry affectionate addresses to his Mistresse under the name of Cynthia (London, 1642), pp. 133-35.

25. In contrast Lovelace mocks the notion of a constant female by comparing her to things impossibly static: the hand of a watch, a growing plant, "Or Your Reflection in a Glasse, / Which keepes possession though you passe.” See The Poems of Richard Lovelace, p. 94.

26. See Lynn Enterline, The Tears of Narcissus: Melancholia and Masculinity in Early Modern Writing (Stanford: Stanford University Press, 1995), p. 349. Lynn Enterline's book deals with the melancholic subject in both Tasso and Marvell (among others) in great detail, linking it with Freudian and post-Freudian theory and with poetic language. Her constant references to the myth of Narcissus confirm my approach. However, she analyses encounters with mirrors rather than encounters with women looking into mirrors, and does not include looking-glass poems.

27. See for instance Elise Jorgens's conclusion that the Cavaliers were "not so happy in their cups" as their songs suggest, in "Politics and Women in Cavalier Song: A Report from a Collection of Secular Song Manuscripts," Explorations in Renaissance Culture 15 (1989), pp. 25-48.

28. Elizabeth Cropper, "The Beauty of Women: Problems in the Rhetoric of Renaissance Portraiture," in Rewriting the Renaissance: The Discourses of Sexual Difference in Early Modern Europe, Margaret W. Ferguson, Maureen Quilligan, and Nancy J. Vickers, ed. (Chicago: University of Chicago Press, 1986), p. 175.

29. Grabes, p. 107. Kynaston's poem also echoes the myth that Dionysus was seduced by Hera using a mirror and was then cut into pieces by the Titans.

30. For the mythography of Echo in the Renaissance and later, see John Hollander, The Figure of Echo (Berkeley: University of California Press, 1981), pp. 6-23.

31. See the discussion of the Medusa figure in Dorothy Stephens, The Limits of Eroticism in Post-Petrarchan Narrative: Conditional Pleasure from Spenser to Marvell (Cambridge: Cambridge University Press, 1998), pp. 80-85. 
32. In Ovid, Perseus acts as Pallas' agent and surrenders to her the Gorgon's head which she then wears on her armour. The power of Medusa is essentially a militant female power.

33. This is discussed (with reference to Jonson's Masque of Queens) in Stephen Orgel, "Jonson and the Amazons," in Soliciting Interpretation: Literary Theory and Seventeenth-Century English Poetry, Elizabeth D. Harvey and Katharine Eisaman Maus, ed. (Chicago: University of Chicago Press, 1990), p. 130.

34. "To Chariessa, beholding herself in a Glasse," in The Poems and Translations of Thomas Stanley, Galbraith Miller Crump, ed. (Oxford: Clarendon Press, 1962) pp. 238-39.

35. John Donne, Poems of Love (London: Folio Society, 1958), p. 61.

36. Scott Paul Gordon, The Power of the Passive Self in English Literature, 1640-1770 (Cambridge: Cambridge University Press, 2002), p. 5.

37. Sister Veronica Delany, ed. The Poems of Patrick Cary (Oxford: Clarendon Press, 1978), p. 9.

38. "Lucasta's Fanne, With a Looking glasse in It," in The Poems of Richard Lovelace, C.H. Wilkinson, ed. (Oxford: Clarendon Press, 1930), p. 51.

39. See for example paintings by Giordano, Titian, Giorgione, and Janssens.

40. Rhodes Dunlap, ed., The Poems of Thomas Carew (Oxford: Clarendon Press, 1957), p. 84 .

41. Carew returns to this theme in the conclusion of "To the Painter" when he writes: "Yet your Art cannot equalize / This Picture in her lovers eyes." See The Poems of Thomas Carew, p. 107. Abraham Cowley, unusually, gives precedence to the creativity of the painter: "His all-resembling Pencil did out-pass / The mimick Imag'ry of Looking-Glass." From "On the Death of Sir Anthony Vandike" in The Complete Works in Verse and Prose of Abraham Cowley, Alexander B. Grosart ed. (New York: AMs Press, 1967), p. 138.

42. See Alastair Fowler, Renaissance Realism: Narrative Images in Literature and Art (Oxford: Oxford University Press, 2003), p. 111.

43. See Achsah Guibbory, "Sexual Politics / Political Sex: Seventeenth-Century Love Poetry," in Renaissance Discourses of Desire, Claude J. Summers and Ted-Larry Pebworth, ed. (Columbia: University of Missouri Press, 1993), pp. 206-22.

44. "A looking-Glasse," in The Poems of Thomas Carew, p. 19, and "On his mistres lookeinge in a glasse," p. 132. Carew's poem may derive from Marino's long Eco in which he tries to attract the hapless nymph by offering many visual feasts including his tears as "your shining mirror." The poem is reproduced in full and translated in Baroque Poetry, J. P. Hill and E. Caracciolo-Trejo, ed. (London: Dent, 1975), pp. 76-81. Thomas Stanley produced several versions of Marino's poem. See Galbraith Miller Crump, ed., The Poems and Translations of Thomas Stanley (Oxford: Clarendon Press, 1962), p. 179.

45. Donne goes some way towards this when the lover's tears reflect, and add value, to the lady's face in "A Valediction; of Weeping," but the conceit is not as extreme. 
82 DOSIA REICHARDT

46. D. M. Rosenberg, "The Cavalier Love Lyric and Milton's Paradise Lost," Genre 24:3 (1991), p. 266.

47. See Peter Stallybrass on the role played by different body paradigms for the early modern construction of gender. Peter Stallybrass and Allon White, The Politics and Poetics of Transgression (London: Methuen, 1986).

48. Paradise Lost V.95.

49. See Anne Cotterill, Digressive Voices in Early Modern English Literature (Oxford: Oxford University Press, 2004), p. 169.

50. See Lynn Enterline, “The Mirror and the Snake: The Case of Marvell's Unfortunate Lover,” Critical Quarterly 29:4 (1987), pp. 98-112. 